\title{
DYNAMICS AND EFFICIENCY OF EVENTS TOURISM, FACTORS IN GLOBAL ECONOMIC GROWTH
}

\author{
Raluca Georgiana Stoian ${ }^{1}$, Manuela Liliana Muresan²
}

\begin{abstract}
Meetings, Incentives, Conventions, and Exhibitions (MICE) is an elite segment of tourism linked to business tourism. It has become dynamic worldwide in recent years. The efficiency of tourism events emerges with the connection between the corporate world and world travel organizations. This connection is a dynamic link that is profitable for all parties involved. Currently, about $40 \%$ of the activity and profit is due to worldwide business travel and the event industry. This paper aims to highlight the efficient role of tourism events through the dynamic "Convention Bureau", at both the international and Romanian level, in terms of global economic growth. We found from the study of this activity sector that one of the important directions of innovation and raising the competitiveness of the tourist offer of any country is given the additional service diversification by stimulating tourism dynamics of events. The advantages and benefits that may be mentioned in business events tourism are revenues from services such as accommodation, facilities conference, catering, leisure, transport and entertainment. These revenues are stimulating the growth of the world economy.
\end{abstract}

JEL Classification Numbers: A1, M2, O4, Z32, DOI: http://dx.doi.org/10.12955/cbup.v4.745

Keywords: tourism events, associations, Convention Bureau, economic growth.

\section{Introduction}

A fascinating field, both in terms of economic development and the services involved, is represented by the tourism category: Meetings, Incentives, Conventions, and Exhibitions (MICE). In the past 1520 years, according to Stănciulescu (2004), event tourism has become the most dynamic and profitable of all existing forms of tourism. Thus, the travel motivation of tourists worldwide is rapidly changing; with more individuals or groups traveling to participate in international conferences, diplomatic meetings, specialized fairs, business forums, training or specialized workshops, and teambuilding affairs organized by companies to boost employees' performance and collaboration skills.

The events and business tourism, according to Minciu (2007), involve people traveling officially for work, commercial, business, educational, or medical purposes. Economic efficiency and development of events, such as business tourism, and studied especially in terms of economic effects, is in direct relationship with the volume, diversity, and quality of tourism benefits or additional tourist services. National and international practices show that an important direction of innovation and raising competitiveness tourist offers, in any country, is represented by additional service diversification, through stimulating tourism dynamics of events.

It is worth mentioning that tourism events are not dependent on the distribution and quality of natural factors or human elements that attract tourists in general, but rather they depend on infrastructure and breadth of service or benefits offered or both. Thus, business travelers attending events are more demanding, less interested in cost, but more concerned about status; these individuals are sophisticated consumers of first class services. Tourism dynamics of events show a recent growing trend, closely related to global economic development, opening of new markets, and the intensification of relations and international collaborations of all kinds.

\section{Description Concepts of event and business tourism}

In literature regarding this domain, we find the concept of "event" in different contexts, from a simple happening to an important social, economic, cultural, sports, and educational manifestation (e.g., conference, meeting, festival, Olympics, or fair), but also as a challenging experience or unforgettable life experience (e.g., adventure or holiday). Organizing events, such as demonstrations, has an important role in the business tourism. According to Davidson \& Cope (2003), a trip in which

\footnotetext{
1 Raluca Georgiana Stoian, Doctoral School of Business Administration, Bucharest University of Economic Studies, Bucharest, Romania, ralucageorgiana.stoian@ gmail.com

${ }^{2}$ Manuela Liliana Muresan, Doctoral School of Business Administration, Bucharest University of Economic Studies, Bucharest, Romania, manuela.muresan@stud.ase.ro
} 
individuals are paid to work and travel, although they are far from home and their corporate office, represents travel in business tourism. Minciu (2007), describes the multitude of events organized in various industries, such as business tourism involving international and national symposiums, diplomatic meetings and visits, economic and trade talks, festivals, and cultural, medical, and research congresses, but also large sporting competitions. Where these activities involve remuneration, they remain a tourism category because they involve the consuming of services in the tourism sector.

Figure 1: Typology of planned event from a tourism perspective

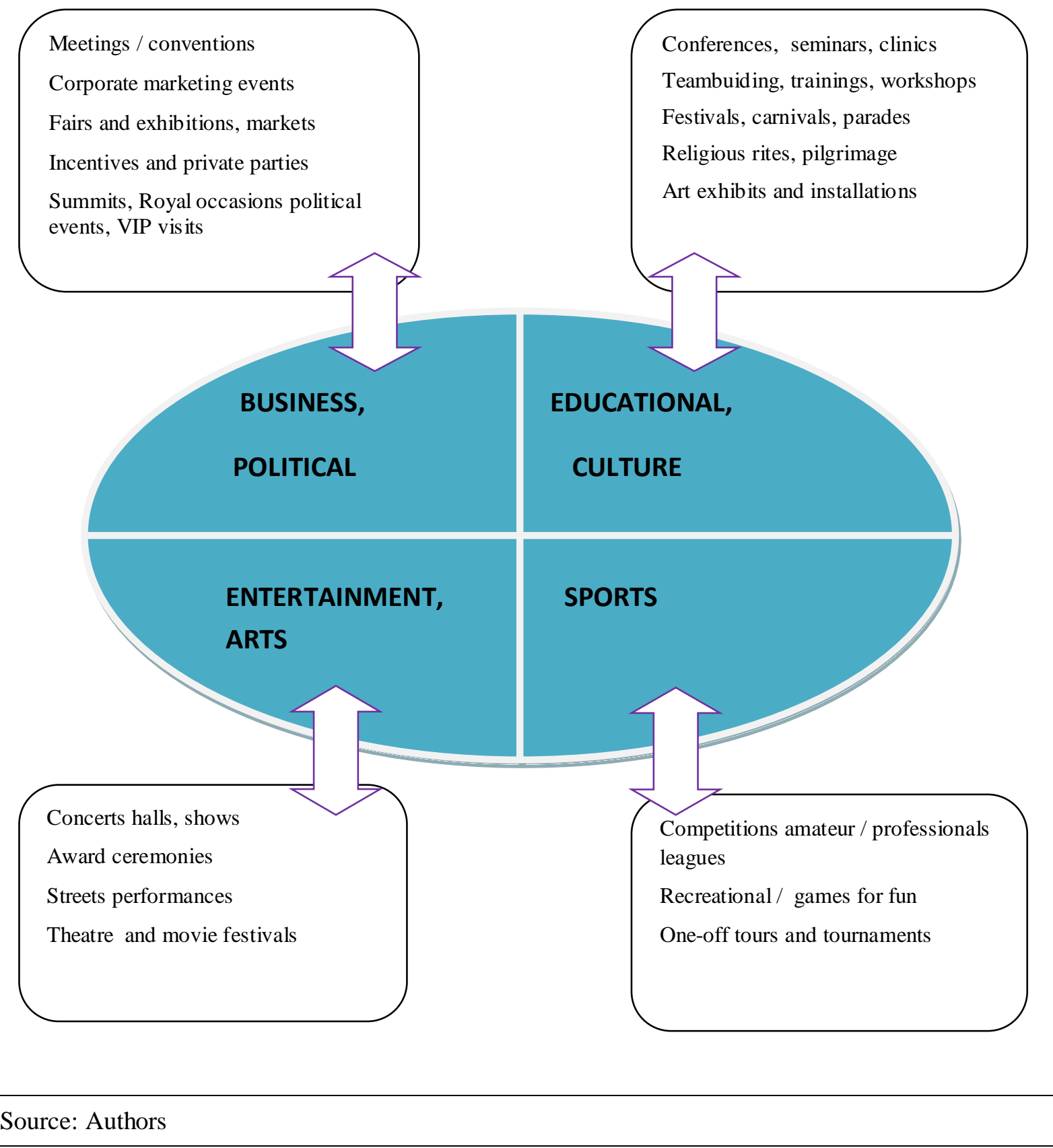

"Event tourism" connects the corporate world with influential organizations in the world of travel. At present, about $40 \%$ of the world travel for many travel agencies is represented by the tourism of events, with budget accommodation per night increasing by about $20 \%$ per tourist. Nevertheless, Davidson \& Cope (2003) believed that stakeholders considered cultural diversity and work-life balance because partly conference participants prefer to be accompanied by a partner, and this 
involves developing additional tourism packages. Thus, profit and growth is guaranteed by finding the best deals and related services, such as small tours and excursions. This situation provides an opportunity to promote the event location. A delegate to an event or conference, is worth five leisure travelers, resulting in economic growth (Badulescu, 2013).

Literature presents business events in tourism as consisting of several types, that according to Chiriac (2004), have a common factors in having activities organized for business purposes and, especially, they embody MICE: meetings (general or business), incentives (rewards and travel programs), congress (conferences, congresses, and conventions), and expositions (exhibitions and trade fairs).

The event name differs between countries, for example, a meeting is regarded as a small gathering, but a large gathering is usually referred to as a conference in the United Kingdom (UK), a convention in the United States of America (USA), and a congress in the European Union (EU) (Swarbrooke \& Hower, 2002). The figure 1 describes the types of events from the perspective of tourism areas.

\section{Dynamics and Efficiency of Business Events Tourism in International and Romanian Economic Growth}

Event tourism began to exponentially grow in efficiency, dynamics, and economics in 2008 . We compared statistics from January and July 2008 and 2015 with the same months in 2007 and 2014 using data from the Romanian National Statistics Institute 2007-2008 and 2014-2015 year. This showed, that in Romania, employment of foreign workers grew during January 2008, compared with the same month in the preceding year. Both arrivals and overnight stays of tourists using accommodation and event services had risen by $6.9 \%$ and 5.1\%, respectively, in January 2008 compared with January 2007 according to the Romanian National Statistics Institute. In July 2008, compared to the same month in the previous year, the arrivals in tourists at establishments with accommodation and event services have increased by $2.7 \%$, while overnight stays decreased by $0.9 \%$. In addition, in July 2008 arrival of foreign visitors at Romania border entry points grew by $8.1 \%$. From January 1 to July 31, 2008, the tourist arrivals at establishments accommodation and event services rose by $3.1 \%$, while overnight stays registered a slight decrease of $0.1 \%$, compared to the same period in the previous year. In 2015, tourist arrivals were also high compared to 2014. In January 2015, compared to the same month in the previous year, both arrivals and overnight stays at establishments with accommodation recorded $17.1 \%$ and $17.7 \%$ growth. In January 2015 , compared to January 2014, border crossings records showed arrival of foreign visitors had increased by $18.6 \%$. In July 2015 , compared with the same month of the previous year, both arrivals and overnight stays at establishments with functions of accommodation registered increases of $24.8 \%$ and $20.8 \%$, respectively, and the borders crossing records showed foreign arrivals had increased by $13.3 \%$ (The Romanian National Statistics Institute, 2007-2015).

This data shows that Romania has opportunities to become one of the most popular countries in Eastern Europe in terms of business events tourism, as it is a destination with unaltered natural, cultural, and historical values, in the European area with easy accessibility by air from all European capitals. Infrastructure is needed for modernization. Tourist hospitality is present in the hospitality industry, and the professional capacity of Romanian companies for organizing large-scale meetings is evident in business centers of hotel chains, such as Marriott, Hilton, Intercontinental, Sheraton, and Sofitel.

Internationally, according to "Trends in international association meetings from North America 2015" by the International Congress and Convention Association - ICCA (2015), research, business event tourism has experienced a significant increase in profits and occupancy of hotel services. During 2014-2015, tourism budgets increased by 15\% i.e. from 38\% in 2014 to $43 \%$ in 2015, with a significant number of international events held in Europe (43\%), compared to countries like Australia (10\%), Asia (20\%), North America (13\%), and Middle East (5\%).

\section{Determinants that Influence the Dynamics and Efficiency of Events Tourism}

Recent social and economic transformation of society have affected the tourism sector dynamics and efficiency. According to Chiriac (2004), factors such as economic globalization, social, and political influences add flexibility to making offers on the market. In addition, technological innovation, 
Internet, and artificial intelligence mean using new means of communication on a larger scale, resulting in increased operating speed within this sector. We note the following order of preferences of tourists: business events with tourism, exotic destinations, short vacations or city breaks.

The advantages and benefits of event tourism are the revenues from accommodation, conference facilities, catering, leisure, transport, and entertainment. Most often participants attending meeting are people with disposable income. Earnings from advertising and tourism promotion of the venue for the event are obtained through having a business tourist leaving the conference or fair satisfied and who becomes a free ambassador for that destination. We consider the greatest advantage delivered by this sector relates to the timing of the event. Most often these meetings are held in the off-peak season to mitigate the effects of seasonal tourism. Also, business travelers are the friendliest visitors to locations where the event takes place, as they are mostly busy with the development of the event, and so they interact only slightly with the local population. Internationally, a rotation of events principle applies in event tourism, which favors equally all members of an organization holding meetings, congresses, or fairs.

\section{Associations - International Convention Bureau}

Event tourism is the most profitable segment of the tourism industry. Hence, industry conferences and events continue to change worldwide. Developing these associations, such as Convention Bureau, which includes specialists from sectors dedicated to services involved in organizing conferences, congresses, seminars, fairs, and specialized exhibitions, namely: agency tour operators, business centers, conference centers, hotels with event facilities, service and equipment providers (e.g., audiovideo, translators, interpreters, advertising, marketing, and media), and transportation providers, banks, insurance agencies, and cultural sites of entertainment. The purpose of these associations is to promote unified deployment in the venues holding event, but also to advise and support the organizers of that event.

This type of association began in 1896, when the first Convention Bureau was established in the USA, according to Spiller (2002), as the Destination Marketing Association International - DMAI (2016) that had its origins there since 1915. It is one of the largest and most trusted resource associations worldwide for official destination marketing organizations (DMOS), also called Convention Bureau (CVBS). Such an association is primarily a passionate advocate for its members. The DMAI is dedicated to improving the efficiency of 4,100 professionals from nearly 600 destinations in approximately 15 countries, through educational programs, networking opportunities, and marketing benefits of available travel.

Another convention bureau association that internationally performs well is the International Congress and Convention Association - ICCA (2016) this association was founded in 1963 by a group of travel agents to shape the future and value of international meetings through a global community consisting of MICE professionals with the knowledge of industrial fabrication and producing successful outcomes in a competitive market of business tourism events. Currently, ICCA is represented by specialists in organizing, transporting, and accommodating international events with participants from over 90 countries worldwide and more than 1,000 companies. Those who wish to plan an international event can rely on the ICCA network to find solutions to all objectives of the event, e.g., venue selection, technical advice, assistance with delegate transport, meeting planning, or other services. The ICCA members are from the uppermost popular destinations worldwide and include experienced specialist suppliers with headquarters in the Netherlands and regional offices in Malaysia, South Africa, Saudi Arabia, USA, and Uruguay.

The Association of Professional Congress Organizers International Association - IAPCO (2016) began in Europe in 1968, it started in Brussels by four MICE professionals, Jean Destree, Eric FIIs, Albert Cronheim, and Pannel Fay, who led the association up until 1971. The IAPCO mission was to raise professional standards among its members and other sectors of the industry through continuing education meetings and interaction between professionals, and this mission is still held globally by its members and partners.

Some years later, in 1972, the International Meeting of Professionals - MPI (2016) was founded in 1972, with headquarters in Dallas, Texas, USA. This is also the most vibrant global association for 
business tourism meetings events worldwide that offers innovative and relevant education, opportunities, and business exchange in their network, but also acts as a prominent voice for promotion and industry growth for MICE. Membership consists of about 17000 members who belong to 80 companies and clubs in 24 countries.

\section{Associations - Convention Bureau in Romania}

In Romania, the Romanian Convention Bureau - RCB (2016) association has been in operation since 1997, and a full member of ICCA since 1999. It is consists of professional organizers of conferences and exhibitions. It brings together more than 60 public and private companies in the areas of the MICE industry that are capable of providing services for congresses, conferences, seminars, and fairs. Through their expertise, RCB members manage about 800 events, involving 100 fairs, and 600 congress, conferences, exhibitions, product launches, or trainings. Approximately 2 million participants annually attend these events.

A new association emerged in 2013. This organization the Industry Events Professionals Association of Romania (APIER) engaged all MICE. Its aim is focused on two directions: promotion of Romania as a MICE destination and professionalization of MICE courses, trainings, presentations, and debates. The prime difference between the two associations, the Romanian Convention Bureau (RCB) and the Industry Events Professionals Association of Romania (APIER), is represented through membership with the Romanian Convention Bureau members comprising companies and professionals in the field of APIER, being a structure that addresses professional individuals. In contrast, the MICE Academy involves a concrete effort to train professionals in the MICE field. The MICE associative sector in Romania is currently experiencing a period of growth and identification of their international potential.

Business event tourism is the only component of the Romanian hospitality industry that is highlighted by increased profits and revenues, and effective for urban hotels, positioning business events tourism in total income to a level of $70 \%$. Most customers are Europeans from Hungary, Germany, Italy, Turkey, Poland, France, Austria, Czech Republic, Austria, UK, and the Netherlands.

\section{Convention Bureau Associations Influence on Global Economic Growth}

The professional organization of conferences, meetings, and other events can be considered the most effective and profitable component of tourism. The impact of the MICE industry on the economy is significant. In the USA, where in 2011, the industry consisted of 1.7 million jobs, $\$ 106$ billion was contributed from the state budget. Of this, $\$ 263$ billion were spent on services, and $\$ 60$ billion on arrivals, and the share of taxes from these operations stood at $\$ 14.3$ billion federally and $\$ 11.3$ billion, locally. However, in Europe, the German MICE industry brings annual revenues of $\$ 65$ billion, i.e. over 30\% more than in the UK (Trends in International Association Meetings from North America Survey Report, 2015). In analyzing the purpose of these associations, one can see that they offer a framework focused on cultural exchange of information, new collaborations in all business sectors worldwide, and partnerships of innovation for the MICE industry events of business involving pleasure travel, as the connection, according to Davidson \& Cope (2003). The money that revolves in this industry and which offers services within fierce level of competition at all levels in this dynamic economy, will increase year to year worldwide. Getz (2003) presents China as the most dominant player in the MICE industry, especially Asia-Pacific, in areas of exhibition and event organization sites in 2011 covering a total of 4.7 million meters or $15 \%$ of the total area worldwide. Thus, China occupies 2nd place after the USA, which is followed by Germany in Europe, regarding the ability to organize meetings.

\section{Conclusion}

To ascertain dynamism and efficiency of global economic growth, business events tourism needs strong support from all global stakeholders. First, we consider innovation and development as crucial, as well as a policy to attract investments in infrastructure and a greater number of participants to organize meetings. Second, the industry must follow the upward trend displayed elsewhere in modern accommodation, quality of customer service, technological innovations in the business and meeting centers, professionalism and hospitality from event organizers, but more so an international strategy to promote business tourism events worldwide through public and private partnerships. 


\section{References}

Badulescu, T. (2013, February). Event Tourism, a gold mine for Romania. Retrieved from http://www.traianbadulescu.ro/2013/02/19/turismul-de-evenimente-o-mina-de-aur-pentru-romania/

Chiriac, A. C. (2004). Tourist assistance in organizing events, Bucharest, THR-CG Publishing.

Davidson, R., \& Cope, B. (2003). Business Travel - Conferences, Incentive, Travel, Exhibitions, Corporate Hospitality and Corporate Travel, London, Prentice Hall Publishing.

Getz, D. (2003). Sport event tourism: planning, development and marketing. In S. Hudson (Ed), New York, Haworth Publishing.

Minciu, R. (2007). Tourism economy, Bucharest, Uranus Publishing.

Spiller, J. (2002). History of convention tourism. In K. Weber \& K. Chon (Eds), Convention tourism: International research and industry perspectives, New York, Haworth Publishing.

Stănciulescu, G. (2004). Management of Tourism Operations, Bucharest, Allback Publishing.

Swarbrooke J., \& Hower S. (2002). Business Travel and Tourism, London, Butterworth Heinemamms Publishing.

The Destination Marketing Association International - DMAI (2016). Retrieved from http://www.destinationmarketing.org/who-we-are

The International Association of Professional Congress Organizers International Association - IAPCO (2016). Retrieved from http://www.iapco.org/all-about-iapco/council/members/

The International Congress and Convention Association - ICCA (2015). Retrieved from http://www.iccaworld.com/nlps/story.cfm?nlpage $=567$

The International Congress and Convention Association - ICCA (2016). Retrieved from http://www. iccaworld.com/abouticca.cfm

The International Meeting of Professionals - MPI (2016). Retrieved from http://www.mpiweb.org/About The Romanian Convention Bureau - RCB (2016). Retrieved from http://www.infotravelromania.ro/rcb.html The Romanian National Statistics Institute (2007-2015). Retrieved from http://www.insse.ro/cms/ro/content/turism Trends in International Association Meetings from North America Survey Report (2015). Retrieved from https://gallery.mailchimp.com/620ef227ca4419ebb370f38d4/files/Association_Survey_2015_MCIntl.pdf 